\title{
Design of a sentence identification test with pictures (TIS-F) based on the pediatric speech intelligibility test
}

Fernanda Freitas Vellozo(1) Ana Paula Leonardi Dellaméa(1) Michele Vargas Garcia ${ }^{(1)}$

(1) Universidade Federal de Santa Maria UFSM - Santa Maria (RS), Brasil. Research conducted at the Undergraduate Program in Speech Pathology, Federal University of Santa Maria - UFSM - Santa Maria (RS), Brazil.

Conflict of interest: Nonexistent

Received on: April 04, 2017 Accepted on: October 17, 2017

Mailing address:

Fernanda Freitas Vellozo

Rua Marfisa Franco Rosa, $n^{0} 07$,

quadra 32, Bairro Tancredo Neves

CEP: $97032-320$ - Santa Maria -

RS - Brasil

E-mail: fevellozo@yahoo.com.br

\section{ABSTRACT}

Purposes: to design a sentence identification test with pictures for adults (Teste de Identificação de Sentenças com Figuras (TIS-F)) as an alternative for evaluation of auditory figure-background ability for verbal sounds, based on the Pediatric Speech Intelligibility Test and also for assessment of unskillful individuals who cannot accomplish other tests with higher levels of difficulty and greater demands.

Methods: the Adobe Illustrator software was used and the image vectorization technique applied for figures creation. The sentences and the competitive message were audio-recorded in a sound treated room by a female announcer, using the software REAPER - FM Digital Audio Workstation.

Results: the TIS-F consisted of a $32 \times 45 \mathrm{~cm}$ card, containing 10 figures, each one measuring $12 \times 12 \mathrm{~cm}$; one compact disc containing a track with the test calibration tone and seven test tracks, each one containing ten sentences and a competitive message and a specific protocol.

Conclusion: the TIS-F is composed of a compact disc with dual-channel recording, with seven tracks containing ten sentences and the competitive story, one card containing ten pictures and a labeling protocol for all presentations and $\mathrm{S} / \mathrm{N}$ in use, as well as the established normality values.

Keywords: Hearing; Speech Discrimination Tests; Test Validation; Auditory Perception; Audiometry, Speech 


\section{INTRODUCTION}

Tests for evaluation of auditory perception differ by type of stimulus (verbal and nonverbal) and type presentation in the ears (binaural or monaural). They are classified according to how the signals are presented, the characteristics of the requested hearing tasks and the method or approach in use. One of the subdivisions in groups or categories for the tests is Monaural Low-Redundancy Speech Tests; Dichotic Tests; Temporal Resolution Test; Temporal Ordering and Temporal Sequence tests; Binaural Interaction or Integration Test ${ }^{1}$.

Monaural low-redundancy tests are those that reduce the extrinsic redundancy of the speech signal. Degraded stimuli are presented by changing time, frequency or intensity of an undistorted signal ${ }^{2}$.

The most commonly used tests in this category are: Filtered Speech Test, Speech-in-Noise Test and Synthetic Sentence Identification Test and its version for children, the Pediatric Speech Intelligibility Test (PSI) with Sentences ${ }^{3}$. According to the classification of these authors, the last two tests are considered to be dichotic tests, because they have a step at which the stimuli are presented to both ears simultaneously.

The Pediatric Speech Intelligibility Test was translated into Brazilian Portuguese by Almeida et al. in1988 4. The original version in English was designed by Jerger et al. ${ }^{5}$, in 1980, for use in children above 3 years old. The test consists of two stages: the dichotic stage, held with a contralateral competitive message (CCM), in which the individual must perform a binaural separation task, i.e. through selective attention, they should distinguish the information presented binaurally; and the monotic stage, performed with an ipsilateral competitive message (ICM), i.e. through selective attention, subjects must distinguish the information presented in one single ear. It should be noted that, for the two steps, subjects use their auditory figure-ground ability 2. This test assesses auditory figure-ground ability for verbal sounds and the combination of auditory and visual stimuli, because subjects must point to the picture corresponding to the phrase they heard, which was presented to them with a simultaneous competitive message ${ }^{2}$.

Recently, new adaptations of auditory perception tests have been made. For the Dichotic Sentence Identification Test (DSI), the authors used the phrases of the Synthetic Sentence Identification Test (SSI) in Portuguese. A combination method was used wherein 45 sentence pairs were formed. Each pair of sentences corresponded to a test item. Also, the Time-compressed Speech Test was adapted. The authors cropped the original recording to reduce application time by decreasing the presentation from 50 to 25 words per ear 6 .

PSI is used in elderly subjects ${ }^{7}$ and is also increasingly used in adult aphasic subjects on in adults suffering from dementia ${ }^{8-11}$. However, it has been originally designed for children. For this reason, this study focuses on the need to prepare new instruments, using pictures to enable the assessment of adults with impaired oral and/or reading skills, since the use of pictorial stimuli increases the redundancy of the test.

Therefore, the aim of this study was to develop a Sentence Identification Test with Pictures (TIS-F) for adults, which may be an alternative to assess auditory figure-ground ability for verbal sounds, based on the Pediatric Speech Intelligibility (TLP) test. It can also be an alternative for evaluation of subjects that cannot take tests with higher levels of difficulty.

\section{METHODS}

This study was approved by the Research Ethics Committee of the Federal University of Santa Maria under protocol number 1316821.

\section{Preparation of images}

To prepare the images of the Sentence Identification Test with pictures (TIS-F), the pictures of the Pediatric Speech Intelligibility Test were used as a model ${ }^{2}$. This test consists of 10 pictures of cats, mice and horses performing different actions. However, for the TIS-F, those images were replaced by images of a woman, a man and a child, respectively, although the actions have been kept the same.

The images were created by an undergraduate student of Industrial Design, with an image vectorization technique, throughthesoftwareAdobe Illustrator. The images were drawn with features that are typicalof a man, a woman and a child in order for them to look as realistic as possible. The authors of this test understand that they designed a new test, instead of adapting the PSI test, because the new images produced a new test as well as new audio tracks, as described below.

\section{Recording of sentences and competitive message}

Based on the new images, the sentences with the new characters were recorded. The recordings were made by a sound technician, in a studio and in a 
soundproof room. The software REAPER - FM Digital Audio Workstation and an Audioarts D75 Digital Audio Console were used for recording purposes. A RE27 Electro - Voice microphone was used as well.

In one channel, the introductory sentence ("show me the") preceding each sentence and the phrases were recorded. In another channel, the competitive message (the story) was recorded. Both the sentences and the competitive message were recorded by the same female announcer in order to maintain the level of difficulty of ipsilateral-contralateral competition.

The material was composed of seven lists, each containing ten sentences in different orders, following the same form of presentation of the PSI, for the application of different $\mathrm{S} / \mathrm{N}$ ratios. The ten sentences were recorded and later copied into the seven different tracks.

The sentences were spoken in approximately 3 seconds, with a 10-second interval between them. The interval between the sentences was meant for the subjects to look for the correct picture that matches the sentence they heard. The times for enunciation of the sentences and for the intervals are the same used in the PSI test.

In the sentences, the verbs "putting" and "drinking" were replaced by "placing" and "taking", in order to make the action clearer so that the sentences could be more easily understood.

The competitive message was the same used in the PSI test, ${ }^{12}$ but it was recorded with the same voice of the speaker of the new sentences.

Subsequently, the calibration tone for the TIS-F was created by the sound technician, after the sentences had been recorded. This tone wasset at $1000 \mathrm{~Hz}$, and it was calibrated for the TIS-F in the audiometer by an engineer who is an expert in calibration of audiological equipment. The following equipment was used: Bruel \& Kjaer 2250 sound pressure level meter, Brue I\& Kjaer 4231 Sound Level Calibrator, Bruel \& Kjaer 4152 Acoustic Coupler (artificial ear) and Bruel \& Kjaer 4144 Pressure-field Microphone. Each channel of the audiometer was calibrated by using a VU-meter. One channel contained the sentences and the other contained the competing message. They were set at level zero, together with the calibration tone.

When comparing the TIS-F with the PSI, there was a difference in intensity between them of approximately
$7 \mathrm{~dB}$. PSI had lower intensity because of a difference in the calibration tone. Thus, TIS-F, at the $\mathrm{S} / \mathrm{N}$ ratio -40 , in the contralateral competitive stage, appeared to be more intense,therefore uncomfortable. As a result, intensity had to be adjusted.

For this purpose, seven raters were invited. They are speech therapists with expertise in auditory processing, and they were verbally invited by the researcher. The raters signed an Informed Consent For Raters whereby their participation in this study was authorized.

As a standard procedure, pure-tone threshold audiometry was carried out and the intensity levels for presentation of the test were added to the three-tone average. All raters had hearing thresholds within normal limits in both ears ${ }^{13}$.

Subsequently, they took both tests in the contralateral competitive stage at the $S / N$ ratios of $-40 \mathrm{~dB}$ for the PSI and at $-40 \mathrm{~dB},-35 \mathrm{~dB}$ and $-30 \mathrm{~dB}$ for the TIS-F. In the next stage, they reported which level of intensity caused most comfort in TIS-F, and which level of intensity appeared to have the same degree of difficulty than the one used in the PSI.

Two of the seven raters reported no discomfort at the $S / N$ ratio of $-40 \mathrm{~dB}$; five reported a great deal of discomfort at the -40 and $-35 \mathrm{~dB}$ ratios and agreed that the $-30 \mathrm{~dB}$ ratio had similar level of comfort and degree of difficulty than the ones in the PSI test. Therefore, they suggested that the intensity of application to be used in the TIS-F should be $-30 \mathrm{~dB}$ in the contralateral competitive stage. The other $S / R$ ratios did not need to be investigated because no discomfort was reported for them.

After intensity was defined, a specific protocol was developed for the TIS-F, similarly to the original protocol of the PSI, which contained the test name, the authors, the data for patient identification and space for marking performance, at different $\mathrm{S} / \mathrm{N}$ ratios. In addition, in order to complement the assessment protocol, the following boxes were included: one for the reference values, one to mark whether or not the assessed ability had changed and one with the captions for the acronyms in use.

\section{RESULTS}

The final result is a $32 \times 45 \mathrm{~cm}$ card with ten pictures, each measuring $12 \times 12 \mathrm{~cm}$, distributed in the same card, as shown in Figure 1. 

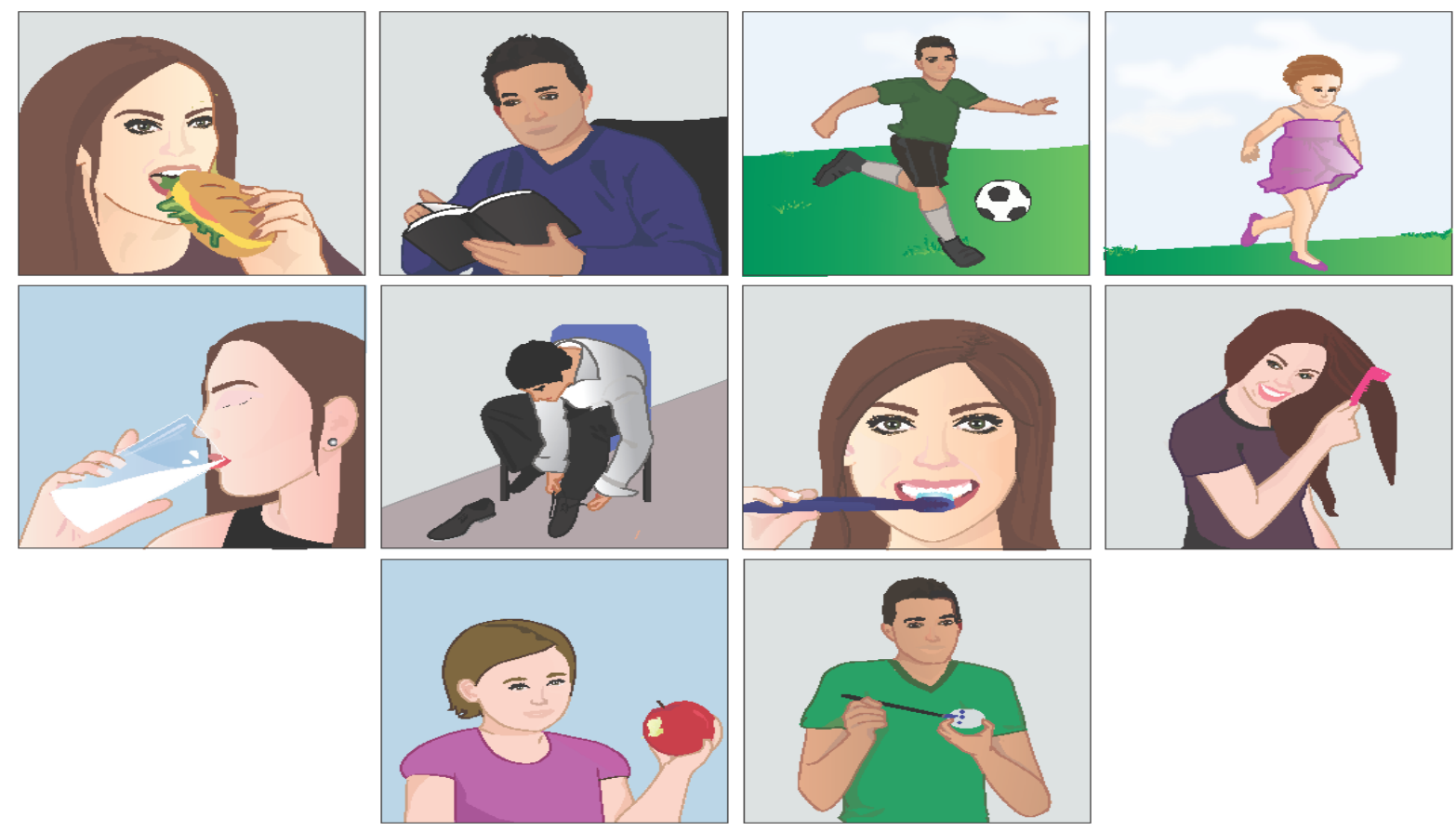

Source: (VELLOZO, DALLAMÉA and GARCIA)

Figure 1. Pictures designed for the Sentence Identification Test with Pictures (TIS-F)

The recording resulted in a compact disc, with seven mp3 tracks, with ten sentences in each (Figure 2), and the competitive message (Figure 3). The first track lasted for 1:49 minutes and contained the introduction with the test name, while the other six tracks lasted for 1:42 min, 01:41 min, 01:43 min, 1:41 min, 1:43 min and $1: 55 \mathrm{~min}$, respectively.

\begin{tabular}{|c|}
\hline Mostre a mulher comendo sanduíche \\
\hline Mostre o homem lendo o livro \\
\hline Mostre o homem jogando futebol \\
\hline Mostre a criança correndo \\
\hline Mostre a mulher tomando leite \\
\hline Mostre o homem colocando o sapato \\
\hline Mostre a mulher escovando os dentes \\
\hline Mostre a mulher penteando o cabelo \\
\hline Mostre a criança comendo a maça \\
\hline Mostre o homem pintando o ovo \\
\hline
\end{tabular}

Figure 2. Sentences created for Sentence identification Test with pictures (TIS-F), translated into Brazilian Portuguese 
"Pedro nasceu! Pedro nasceu! Joana entrou pela casa aos pulos contando à mãe.

- Que Pedro é esse? A mãe perguntou sem compreender 0 alvoroço da filha.

- 0 pé de milho mãe. Aquele que o pai plantou no quintal. Um fiozinho de cabelo verde.

Ela viu quando a semente foi posta na terra.

- 0 pai, com a ponta do canivete velho, esgravatou num pedacinho de chão.

- Se não faltar chuva, Na. Era como o pai a chamava

- Vai nascer um pé de milho.

E diante do seu espanto!

- Sim senhora, um pé de milho, muito maior do que a senhora, e vai sair desta sementinha de nada.

0 coração de Joana, como a terra, recebeu o pequenino grão de milho.

A mãe ralhou: - Onde já se viu o pé de milho ter nome menina! E logo o nome do seu pai.

Ela apontou com a covinha do queixo para a boneca que trazia no colo.

- Na Beatriz, eu pus o seu, mãe.

E voltou às pressas para 0 quintal.

Estacou-se de repente! Apertou a boneca contra 0 peito, abaixou-se para ver melhor o fiozinho de cabelo verde em que 0 sol apagava 0 orvalho.

- Ele está secando.

Os cabelos de Joana eram escorridos para trás. Joana amava o vento e a chuva. Não era fácil fazê-la desistir de alguma coisa que the houvesse entrado no coração.
A morte tinha ferido Joana uma vez, quando encontrou a Pepe caída na borda do lago da praça da igreja, onde a patinha costumava ir banhar-se.

Correu para o pai. - A Pepe está dormindo dentro d'água.

No dia seguinte, como não visse a companheira, perguntou:

- A Pepe já acordou pai?

- Não sei se a Pepe vai acordar, Na!

- Nem amanhã?

- Nem.

- Nem depois de depois de amanhã?

- Nem.

- Nem daqui a mil anos?

- Nem.

Joana teve medo que um sono igual levasse para longe dela 0 pé de milho.

- Não quero que o Pedro não volte mais como a Pepe.

A mãe puxou-a para junto de si.

- Deixe dessas histórias menina! Com oito anos que você tem era tempo para ser menos boba.

Joana ergueu o rostinho, olhou a mãe dentro dos olhos, os seus estavam molhados e seus beicinhos tremiam.

- Ele está com sede mãe!

E soltando-se dos braços maternos, como uma andorinha que já sabe voar, foi procurar o vento."

Source: Goulart (1984)

Figure 3. Competitive Message used in the Sentence Identification Test with Pictures (TIS-F). Story translated into Brazilian Portuguese

Figure 4 shows the protocol for the TIS-F, containing subject identification data, space to mark the subjects' performance in each step of the test, and the previously established reference values.

Figures 5 and 6 show a difference in noise when recording the tests, through a spectrogram. There is less noise for the TIS-F.

\section{DISCUSSION}

The pictures of the PSI test are composed of ten images, always with the same characters (Tom - cat, Jerry-mouse and a horse), but with some differences in color between them. The cat appears with different color on the ears (black) when it is brushing its teeth. The mouse is not gray and wears a uniform when playing soccer and when putting shoes on.
An attempt was made in the present study to keep the same idea of PSI for the images of the TIS-F, i.e. to create similar but not identical images (Figure 2). In the picture with the woman, for example, the features are different but she has the same hair color. The child is not identical but wears the same color in clothes. The man is very similar, except for the picture in which he is putting his shoes on.

The motivation of this study was to identify the need to use this type of test in clinical practice. Previous research conducted with the PSI (because more demanding tests could not be applied) in adults with impaired language skills and elderly showed that there were no tests suitable for this particular population with visual and/or communicative impairments ${ }^{7-11}$. Thus, the TIS-F was created with more realistic pictures so as 
Teste de Identificação de Sentenças com figuras (TIS-F).

FERNANDA FREITAS VELLOZO E MICHELE VARGAS GARCIA, 2016

\begin{tabular}{|l|l|}
\hline Nome: & Idade: \\
\hline Avaliador: & Data da avaliação: \\
\hline
\end{tabular}

Desempenho

\begin{tabular}{|c|c|c|c|c|c|c|c|c|c|c|c|c|c|}
\hline \multicolumn{14}{|c|}{ Etapa Dicótica } \\
\hline $\begin{array}{l}\text { Orellha } \\
\text { Testada }\end{array}$ & $\begin{array}{l}\mathbf{M} \\
\mathbf{d B} \\
\mathrm{NA}\end{array}$ & $\begin{array}{l}\text { MC } \\
\text { dB } \\
\text { NA }\end{array}$ & Relação & 1 & & 3 & s & 6 & 7 & 8 & 9 & 10 & $\begin{array}{c}\text { Acertos } \\
\%\end{array}$ \\
\hline OD & & & $0 / \mathrm{MCC}$ & & & & & & & & & & \\
\hline OD & & & $-30 / \mathrm{MCC}$ & & & & & & & & & & \\
\hline $\mathrm{OE}$ & & & $0 / \mathrm{MCC}$ & & & & & & & & & & \\
\hline $\mathrm{OE}$ & & & $-30 / \mathrm{MCC}$ & & & & & & & & & & \\
\hline \multicolumn{14}{|c|}{ Etapa Monótica } \\
\hline $\begin{array}{l}\text { Orelha } \\
\text { Testada }\end{array}$ & $\begin{array}{r}\mathrm{M} \\
\mathrm{dB} \\
\mathrm{NA} \\
\end{array}$ & \begin{tabular}{|} 
MC \\
$\mathrm{dB}$ \\
$\mathrm{NA}$ \\
\end{tabular} & Relação & 1 & & 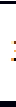 & & 6 & 7 & 8 & 9 & 10 & $\begin{array}{c}\text { Acertos } \\
\%\end{array}$ \\
\hline$O D$ & & & $0 / \mathrm{MCI}$ & & & & & & & & & & \\
\hline$O D$ & & & $-10 / \mathrm{MCI}$ & & & & & & & & & & \\
\hline$O D$ & & & $-15 / \mathrm{MCI}$ & & & & & & & & & & \\
\hline $\mathrm{OE}$ & & & $0 / \mathrm{MCI}$ & & & & & & & & & & \\
\hline $\mathrm{OE}$ & & & $-10 / \mathrm{MCI}$ & & & & & & & & & & \\
\hline $\mathrm{OE}$ & & & $-15 / \mathrm{MCI}$ & & & & & & & & & & \\
\hline
\end{tabular}

Valores de Referência:

\begin{tabular}{|c|l|c|}
\hline Teste & \multicolumn{1}{|c|}{ Situação } & Para normo-ouvintes de 18 a 33 anos \\
\hline TIS-F & $\begin{array}{l}\text { MCC nas relações S/R zero dB e }-30 \mathrm{~dB} \\
\text { MCI nas relações S/R zero e }-15 \mathrm{~dB}\end{array}$ & $100 \%$ de acertos \\
\hline
\end{tabular}

Avaliação da habilidade auditiva de figura-fundo associada a estímulos auditivos e visuais:

\begin{tabular}{|ll|}
\hline () normal & () alterada \\
\hline
\end{tabular}

Legenda:

\section{$\mathrm{M}=$ Mensagem;}

$\mathrm{MC}=$ Mensagem Competitiva;

MCC = Mensagem Competitiva Contralateral;

MCI = Mensagem Competitiva Ipsilateral;

NA = Nível de Andição;

$\mathrm{OD}=$ Orelha Direita;

$\mathrm{OE}=$ Orelha Esquerda;

$\mathrm{S} / \mathrm{R}=\mathrm{Sinal}$ rúdo;

TIS-F = Teste de Identificação de Sentenças com Figuras.

Referenciar este material como: VELLOZO, F.F; GARCIA, MV. Teste de Identificação de Sentenças com Figuras (TIS-F). Trabalho realizado em uma Dissertação de Mestrado, UFSM, 2016.

Figure 4. Protocol designed for the Sentence Identification Test with Pictures (TIS-M) 


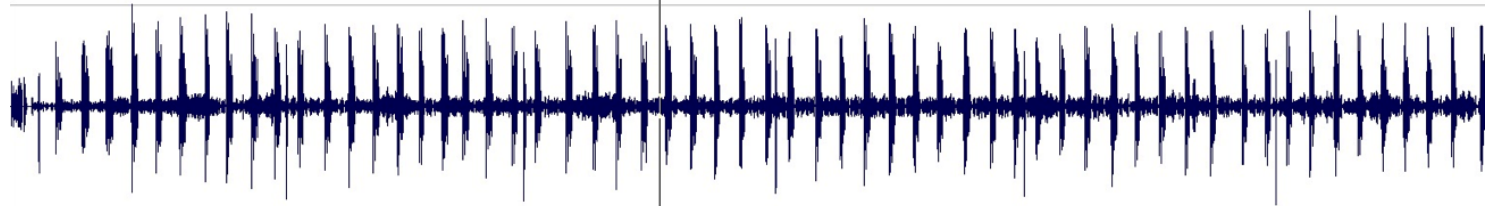

Figure 5. Spectrogram for noise analysis in the Pediatric Speech Intelligibility (SPI) Test. Section cropped from an excerpt of the recorded story

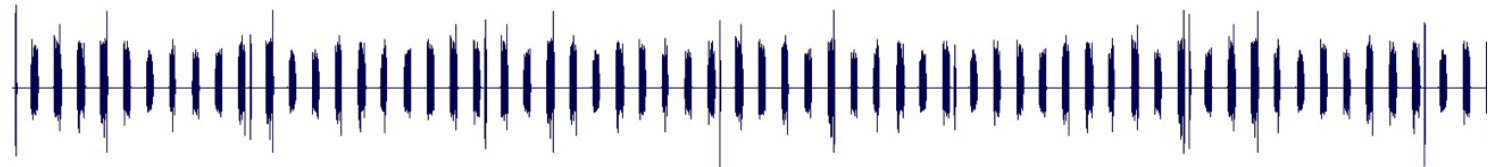

Figure 6. Spectrogram for noise analysis in the Sentence Identification Test with Pictures (TIS-F). Section cropped from an excerpt of the recorded story

to offer a test with greater visual compatibility with this population.

The adaptation or design of auditory processing tests has been recently reported in the literature, but those tests used the original recordings and specific software to edit them.

The authors ${ }^{14}$, when preparing the Brazilian Portuguese version of the Dichotic Sentence Identification Test (DSI), selected the phrases extracted from the Synthetic Sentence Identification (SSI) test in Brazilian Portuguese (from the CD that is part of the material for evaluation of central auditory processing) ${ }^{2}$ and followed a procedure to combine them. According to the authors, a noise gate device had to be used in order to remove the noise from the original recording. Also, the intensity of the sentences had to be increased by six decibels to allow the speaker's voice to be louder. The authors reported that these adjustments were made without affecting the quality of the original recording.

To adapt the Time-compressed Speech Test, the authors ${ }^{6}$ used the editing software Free Audio Editor 2013 to crop the words of the original test (from the CD that is part of the material for evaluation of central auditory processing) ${ }^{2}$ and generate a new file. They kept 25 of the 50 words of the original test. They managed to keep the same recording quality with the advantage of reducing test application time.
Unlike the above-mentioned studies, preparation of the TIS-F required a new recording because the original recording (from the $C D$ which is part of the material for evaluation of central auditory processing) ${ }^{2}$ is the same prepared by Almeida Caetano and Almeida in $1988{ }^{4}$, when they translated PSI into Brazilian Portuguese. At the time, the recording was made on magnetic tape, and there is no description in the original paper about recording conditions. Apparently, no soundproof environment was used.These conditions resulted in loss of recording quality, and there was a high degree of noise, as can be seen in the spectrogram (Figure 5).

Figures 5 and 6 show the difference between the spectrogram of the tests. Figure 5 shows the recording of the TIS-F, which was performed in a soundproof room, i.e., with absence of noise.

Another reason to make a new recording is that the sentences should match the new pictures, hence the original recording could not be possibly used. Therefore, even though the competitive message (Figure 3) is the same used in PSI, it was also recorded again by the current female speaker to provide actual difficulty from competition.

The marking protocol of the TIS-F (Figure 4) followed the lines of the protocol of PSI, in which the rater should mark right or wrong in the box corresponding to the five or ten presentations of sentences at different $\mathrm{S} / \mathrm{N}$ ratios for each ear. Each correct or incorrect answer 
corresponds to $10 \%$ or $20 \%$ if only five sentences were applied. Thus, if a subject answers all items correctly at the same $\mathrm{S} / \mathrm{N}$ ratio, from the same ear, he/she will have a total of $100 \%$ correct answers for each stage.

After the TIS-F material has been prepared, it should be applied in two steps: dichotic and monotic. For the dichotic step, the sentences must be presented in one ear and the competitive message in the contralateral ear.Such presentation is supposed to be made at the zero and $-30 \mathrm{~dB}$ ratios. At the zero $\mathrm{S} / \mathrm{N}$ ratio, only five sentences should be presented. If the subject makes an error, the ten sentences should then be applied. For the $-30 \mathrm{~dB} S / \mathrm{N}$ ratio, the ten sentences should be directly applied. In the monotic step, both the sentences and the competitive message are presented in the same ear. Only five sentences are presented at the zero $\mathrm{S} / \mathrm{N}$ ratio while ten sentences are presented at the $-10 \mathrm{~dB}$ and $-15 \mathrm{~dB} S / \mathrm{N}$ ratios.

The TIS-F was designed to offer another option to the battery of AP tests, to evaluate the auditory figureground ability for verbal sounds in adults and also to provide an alternative test that meets the needs of subjects who cannot take tests with a high degree of difficulty or greater demands.

It should be noted that the development of the TIS-F was never intended to replace a test such as PSI, which is widely acknowledged and corroborated by a great deal of previous studies. The actual intention behind TIS-F is to provide another option for AP assessment with audio cryptography, to speech therapists in clinical practice and in the scientific community. Alternatively, one of the tests can be used for AP while the other, for auditory training, because it is known that one should not use the same test for assessment and for training purposes.

For the TIS-F to be a tool with reliable results, further research must be conducted in different populations with different levels of education and age groups. Moreover, sensitivity analysis is required to detect changes in the auditory figure-ground ability for verbal sounds.

\section{CONCLUSION}

The TIS-F consists of a compact disc a compact disc with dual-channel recording, with seven tracks containing ten sentences and a competitive story, one card containing ten pictures and a marking protocol for all presentations and $\mathrm{S} / \mathrm{N}$ ratios in use, as well as the established values of normality.

\section{REFERENCES}

1. Baran JA. Test Battery Considerations. In: Musiek F, Chermak GD (orgs.). Handbook of (central) auditory procissing disorder: auditory neuroscience and diagnosis. San Diego: Plural; 2007. p. 163-92.

2. Pereira LD, Schochat E. Testes auditivos comportamentais para avaliação do processamento auditivo central. Ed. PróFono; 2011.

3. Pereira LD, Frota S. Avaliação do processamento auditivo: testes comportamemtais. In: Bevilacqua MC et al (orgs.). Tratado de Audiologia. São Paulo: Santos; 2013. p. 293-313.

4. Almeida CIR, Campos MI, Almeida RR. Logoaudiometria pediátrica (PSI)/ Pediatric Speech Inteligibility Test. Rev Bras Otorrinolaringol. 1988;54(3):404-11.

5. Jerger S, Lewis S, Hawkins J, Jerger J. Pediatric Speech Intelligibility Test. I. Generation of test materials. International Journal of Pediatric. Otorhinolaryngology. 1980;2(3):217-30.

6. Folgearini JS, Goulart LLA, Garcia MV. Teste de Fala Comprimida: Adaptação e validação. [Trabalho de Conclusão de Curso, Graduação em Fonoaudiologia] Santa Maria (RS): Universidade Federal de Santa Maria; 2015.

7. Pinheiro MMC, Pereira LD. Processamento auditivo em idosos: estudo da interação por meio de testes com estímulo verbais e não-verbais. Braz $\mathrm{J}$ Otorhinolaryngol. 2004;70(2):209-14.

8. Ortiz KZ, Peroni CV. Compreensão de fala em situação de mensagem competitiva em afásicos. Rev. CEFAC. 2008;10(2):226-32.

9. Zeigelboim BS, Klagenberg KF, LiberalessoPBN, Menezes P, Gonçalvez DV. Avaliação neurofisiológica das vias auditivas e do equilíbrio na afasia de broca - apresentação de um caso ilustrativo. J Epilepsy ClinNeurophysiol. 2010;16(4):143-8.

10. Santos RBF, Marangoni AT, Andrade NA, Vieira MM, Ortiz KZ, Gil D. Behavioral auditory processing evaluation after traumatic brain injury: pilot study. Rev. CEFAC. 2013;15(5):1156-62.

11. Mello JG, Garcia MV, Fedosse E. Multiple aspects of language in dementia: a comparison between domestic and institutional context. Rev. CEFAC. 2015;17(2):615-27.

12. Goulart M. Joana. 4 .ed. São Paulo: Alfa-Omega, 1984. 
13. Lloyd LL, Kaplan H. Audiometric interpretation: a manual o basic audiometry. University Park Press: Baltimore. 1978. p. 16-7.

14. Andrade NA, Gil D, lorio MCM. Elaboração da versão em português brasileiro do Teste de Identificação de Sentenças Dicóticas (DSI). Rev. soc. bras. Fonoaudiol. 2010;15(4):540-5. 